\title{
The Agency Theory Approach to the Public PROCUREMENT SYSTEM
}

\author{
AGNIESZKA CHRISIDU-BUDNIK* \\ JUSTYNA PRZEDAŃSKA **
}

\section{Assumptions to the AgenCy Theory}

The literature on the subject states that the agency relationship is "one of the oldest and commonest codified modes of social interaction"1. At the foundation of the agency theory is the assumption that there is an asymmetry of information between the two parties to a relationship in a given decision-making situation when one of the parties, referred to as the agent, acts on behalf of or represents the other party, referred to as the principal. The analysis of the agency theory helps identify the relativity and mutability of the subject matter of the cognition. The entity participating in the principal-agent relationship can be an individual person, entire groups of people, the state administration or an enterprise. Each party may have different (more precise, fuller) information on the subject of the relationship.

The agency theory has opened up new research perspectives, illustrating the relativity and mutability of the subject matter of the cognition. The subjects of the cognition are the relationships that typically assume the form of formalized contracts in various areas of the economy, such as on the insurance market, in the process of corporate governance, in the human resources management process in the organization, in the process of creating strategic alliances, in public-private partnerships, as well as in contracting for public services and tasks. The agency relationship appears whenever one of the parties must rely on the acts of the other. The agency relationship is a contract, under which the principal engages another person (the agent) to perform specific projects on its behalf, delegating decisionmaking rights ${ }^{2}$. Three further assumptions are made in the agency theory:

DOI: $10.1515 /$ wrlae-2015-0059

* $\mathrm{PhD}$ in Economics, Assistant Professor at the Institute of Administrative Sciences, Faculty of Law, Administration and Economics, University of Wrocław; agnieszka.chrisidu-budnik@uwr.edu.pl

** PhD in Law, Assistant Professor at the Institute of Administrative Sciences, Faculty of Law, Administration and Economics, University of Wrocław; justyna.przedanska@uwr.edu.pl

'Stephen Ross, 'The economic theory of agency: the principal's problem' (1973) 62 (2) American Economic Review 134.

${ }^{2}$ Michael C Jensen, William H Meckling, 'Theory of the firm: managerial behavior, agency cost and ownership structure' (1976) 3 (4) Journal of Financial Economics 305-360. 
(a) the efficiency of the principal's operations depends on the agent's acts and decisions; (b) decisions are made by the parties to the relationship under conditions of uncertainty and $\operatorname{risk}^{3}$; (c) the principal and the agent have conflicting objectives to some extent ${ }^{4}$. The pluralism of the assumptions constituting the central part of the agency theory leads to the focusing of attention on issues of monitoring the activities of one of the parties to the relationship. It is assumed in the classic mainstream of the agency theory that the agent operating on behalf of the principal has the information advantage. The information advantage and the assumption of the existence of a conflict of interests between the principal and the agent can generate opportunistic behaviour on the part of the agent. The term "opportunism" has exactly the same meaning as Olivier E. Williamson assigned to it. He understood opportunism as the desire to implement one's personal interests. Williamson claimed that even the more blatant forms, such as lying, stealing and cheating are included in this. Opportunism is typically based on more subtle forms, involving action, as well as inaction taken up ex ante - even before the conclusion of the contract, in tractu - during the performance of the provisions of the contract, as well as ex post- after the end of the contract $^{5}$.

From the economic point of view, the agency relationship is a strictly optimizing issue, involving the appropriate selection of legal and organizational solutions that reduce the asymmetry of information and/or encourage the agent's activities to be consistent with the principal's expectations. The problem of optimization in the literature on the subject is viewed in the context of the assumption that this asymmetry of information exists, as does a conflict of interests between the principal and the agent - to some extent, each party pursues its own individual objective ${ }^{6}$. This is because, if the agent has a different function, but does not have an information advantage, the principal could create a complete contract encompassing claims in unpredictable conditions. A complete contract is a utopian structure, which falls into the category of the first-best outcome, namely a result of the collaboration of the principal and the agent, such as which would only be achievable in an unreal world of full and/or symmetrical information. The objective of optimization is to form the agency relationship in such a way as to achieve the second-best outcome, which is a result that is as close as possible to the first-best outcome ${ }^{7}$. The problem of optimization also focuses on looking for ways to minimize agency costs, which are higher as the principal's and agent's interests,

\footnotetext{
3 Kathleen M Eisenhardt, 'Agency theory: an assessment and review' (1989) 14 (1) Academy of Management Review 57-74.

${ }^{4}$ Hounaida Daly, 'Conflicts of interest in agency theory: a theoretical overview' (2015) 15

(1) Global Journal of Human-Social Science: E Economics 17-22.

${ }^{5}$ Olivier E Williamson, The economic institution of capitalism (The Free Press 1985) 47.

${ }^{6}$ Jean-Jacques Laffont, David Martimort, The theory of incentives. The Principal-Agent Model (Princeton University Press 2002) 20.

7 John W Pratt, Richard J Zeckhauser, Principal and agents: the structure of Business (Harvard Business School Press 1985) 3; Patrick W Schmitz, 'On the interplay of hidden action and hidden information in simple bilateral trading problems' (2002) 1103 (2) Journal of Economic Theory 444-460.
} 
objectives and values are more divergent. Three categories of agency costs are distinguished:

1. The costs borne by the principal in order to control the agent.

2. The costs borne by the agent in order to build his own credibility and incite the principal's confidence.

3. Opportunity costs, meaning a loss of efficiency by the principal because of the divergence of the objectives of the parties and the difficulty in controlling the agent's activities.

The acceptance of the above view of the phenomenon of opportunism justifies focusing on three aspects of asymmetry of information. The first, adverse selection, appears before the contract is concluded and refers to actions taken by the agent, the objective of which is to encourage the principal to enter into a contract with him. Adverse selection encompasses the phenomenon of hidden information - the agent has knowledge of environmental variables which are not available to the principal. The variables describing the environment can therefore be random, regardless of the agent's actions (e.g., rate of return on an investment project). The agent has an information advantage and can also claim that he has the know-how and resources needed for performing the contract, while the principal does not have the instruments to verify the agent's reliability ${ }^{8}$. The phenomenon of hidden information creates a situation in which the principal can observe the activities, but is unable to identify and verify the external factors affecting the agent's choice of actions 9 .

The second, moral hazard, appears during the performance of the contract and applies to actions taken by the agent, which are difficult for the principal to monitor ${ }^{10}$. Moral hazard involves the phenomenon of hidden action - the agent takes action which cannot be observed by the principal (e.g., the level of effort in implementing an investment project) due to the costs of obtaining the information. Therefore, the principal is unable to identify the relationship between the agent's effort and the result he achieves. The phenomenon of hidden activity creates a situation in which the principal cannot see the agent's actions, only their outcome ${ }^{11}$.

The third, non-verifiability, can take place at the stage of entering into and performing the transaction, or after its completion. It arises when the principal has information about the agent's inappropriate activities, but is unable to validate them and, in this sense, prove them. It is therefore useless, or, in other words, not available to the stakeholders, courts or the public $^{12}$.

\footnotetext{
${ }^{8}$ Caroline Nyman, Fredrik Nilsson, Birger Rapp, 'Accountability in local government: a principal-agent perspective' (2005) 9 (2) Journal of Human Resource Costing and Accounting 123-137.

9 Jacek Miroński, 'Relacja agencji w teorii przedsiębiorstwa' (2005) 164 (4) Gospodarka Narodowa 3; Andrzej Paliński, 'Kosztowna weryfikacja jako element relacji bankkredytobiorca' (2009) 40 (3) Bank i Kredyt 94.

10 Trevor L Brown, Matthew Potoski, David M Slyke, 'Managing public service contracts: aligning values, institutions, and markets' (2006) 66 (3) Public Administration Review 323-332.

${ }^{11}$ Miroński, Paliński (n 9).

12 Jean-Jacques Laffont, David Martimort, The theory of incentives. The Principal-Agent Model (Princeton University Press 2002) 3.
} 


\section{Contracting OUt. Restrictions of the Agency THEORY}

A trend is noticed in the functioning of the public sector regarding the increasing importance of contracts as forms of operation of this sector. This kind of form of fulfilment of public tasks and services has intensified in Europe and the United States under the influence of institutional reforms initiated by U.S. President Ronald Reagan and British Prime Minister Margaret Thatcher. These reforms led to the development of discipline, as well as a set of practices, which are considered a paradigm of New Public Management (NPM), namely, a certain unity of the starting assumptions and methods of discipline, a unity determining its claims and hypotheses. The NPM paradigm is a special and impressive phenomenon. The rate of development of research taken up within different, individual academic disciplines (economics, law, the science of administration, management science, politics and sociology), which identify the advantages and limitations of NPM as a public sector practices, is especially noteworthy ${ }^{13}$. Regardless of the discussions taking place between the representatives of the various academic disciplines, the common denominator of all older and newer theoretical propositions is the focus of attention on the issue of contracting out public tasks and services. The process for contracting out tasks between the public awarding entity and the private entity, which is a contractor, currently assumes the form of a transaction which can be analysed from the point of view of the agency theory.

The analysis of the institution of public contracts from the point of view of the agency theory implies the need to note its limitations. The most comprehensive critical assessment was made by Nilakanta and Rao ${ }^{14}$. Certain limitations of the application attributes of the agency theory arise from the specifics of the public procurement system as one of the forms of contracting out. There is no doubt that there is asymmetry of information on the public procurement market, which can lead to:

1. An increase in agency costs.

2. Problems with the fulfilment of the subject matter of the contract.

3. The cancellation of the public procurement proceedings.

A characteristic element of the public procurement system is the double-sided asymmetry of information. Both the principal (the awarding entity) and the agent (the contractor) can be affected by asymmetry of information. The awarding entity knows which services it needs, but does not always know how to obtain the service on the market to make the contract effective. This especially applies to the lack of knowledge on how to articulate expectations and needs in the terms of reference. Regardless of how the asymmetry of information is distributed among the parties to the

\footnotetext{
${ }^{13}$ Van R Johnston, Paul Seidenstat, 'Contracting out government services: privatization at the millennium' (2007) 30 (3) International Journal of Public Administration 231-247; Graeme A Hodge, 'Competitive tendering and contracting out: rhetoric or reality?' (1999) 22 (4) Public Productivity and Management Review 455-469; George A Boyne, 'Bureaucratic theory meets reality: public choice and service contracting in U.S. local government' (1998) 58 (6) Public Administration and Review 474-484.

14 Venkataraman Nilakant, Hayagreeva Rao, 'Agency theory and uncertainty in organization. An evaluation' (1994) 15 (5) Organization Studies 649-672.
} 
transaction, the adverse consequences of the asymmetry of information will affect the awarding entity to a greater extent. Therefore, the awarding entity should be motivated to gain knowledge to enable it to effectively prepare a description of the subject matter of the procurement.

Public procurement is not only a legal, but also an economic instrument. The decisions made by the awarding entity determine the conduct of the contractors and the effects of fulfilling the contract as early as at the start of the process of awarding the public contract. The analysis of the mechanisms on which the relationships between entities in the public procurement system are based enables a certain, particular feature to be captured. The classic mainstream agency theory assumes that the principal has to rely on the actions of the contractor. From the point of view of effectiveness of public procurement, it is of particular importance that the contractor (agent) first has to rely on the actions of the awarding entity (principal), namely its substantive qualifications. When introducing legal regulations on the method of preparing the description of the subject matter of the contract and the organizational/legal solutions intended to eliminate the asymmetry of information, the lawmakers noted the significance of quality and transparency of the actions taken by the awarding entity at the stage of preparation of the procurement. And it is here where the strict optimizing function of the law mentioned above appears, involving a reduction in the asymmetry of information between the awarding entity and the contractor. The optimizing function of the law at the stage of preparation of the procurement should be considered on two levels.

First, optimization can be considered at the level of the awarding entity's activities, where it is important to formulate its expectations holistically, transparently and objectively for each of the potential contractors. If the awarding entity arrives at the conclusion that its knowledge is insufficient, it may benefit from the services of experts or, for example, take advantage of the institution of the technical dialogue, recognizing that the contractor has an information advantage regarding the subject matter of the procurement.

Second, optimization can be considered at the level of action taken by the contractor if it concludes that it does not have sufficient knowledge regarding the terms of reference. Contractors who have experience and are therefore familiar with the public procurement market, who can anticipate potential problems arising from the vague provisions in the tender documents, for example, the deadline for fulfilling the contract, primarily take advantage of this opportunity. If the contractor arrives at the conclusion that the information contained in the tender documents is insufficient, using its substantive skills and assuming that the awarding entity has an information advantage with regard to its expectations and needs, it can take advantage of the optimization instrument of asking questions. Given that the contractor's substantive skills can determine the success of performing the public contract, the importance and the need for the awarding entity to take account of the comments and reservations raised by the contractors is noticeable in practice.

It should be added that these two levels of analysis regarding the optimization of the functions of the law constitute a part of the mainstream of research, in which the agency theory is perceived from the point of view 
of the theory of authority in any organizational structure ${ }^{15}$. Authority - in relational terms - is interpreted as the ability to exert an influence. Taking into account the so-called authority of the contractor's expert, which enables him to exert an influence on the awarding entity's acts and, simultaneously, benefit from the institution of the awarding entity asking questions, shows that the contractor can modify the awarding entity's behaviour. Similarly, the theory of authority enables the analysis of the agency relationship in public procurement from the point of view of dynamic reciprocity, where the actions taken by the awarding entity and the contractor can be mutually modified under the influence of the impulses coming from each of the parties to the transaction. The launch of this dynamic reciprocity simultaneously enables the reduction of the three types of agency costs mentioned above. At the same time, it should be pointed out that the analysis of the functioning of the Polish public procurement system in practice leads to the conclusion that the awarding entity and the contractor often deliberately do not take advantage of these optional legal instruments, which enable the asymmetry of information between them to be eliminated. There are cases where contractors, being aware of the low level of precision of the provisions of the tender documentation, deliberately do not exercise the right to ask so as to interpret their doubts to their own advantage. This means that some contractors are willing to take the risk, when they estimate that the potential gains can outweigh the potential losses. The awarding entity, which is required to accurately describe the subject matter of the contract, may deliberately not make any efforts to satisfy the obligation of applying the diligence understood in this way, thereby providing potential contractors with the opportunity to reinforce the adverse selection and take advantage of the moral hazard; the latter can be analysed in the context of "possessing" or "not possessing" the appropriate knowledge for the performance of the subject matter of the contract.

The ability to substitute clarity and precision through the multiplicity of interpretations in an area optimizing the function of the law clearly reduces and frequently eliminates the effectiveness of the implementation of the public procurement process at the tendering stage, as well as and the stage of fulfilling the contract. The perspective assumed by the awarding entity and the contractor with regard to the asymmetry of information in the public procurement process could give rise to two types of effects. Firstly, positive, when both parties are aware of the possibility of asymmetry of information arising and are willing to take steps to eliminate it. Information asymmetry is treated as the ambiguity of information, which creates the possibility of the same message being interpreted differently. The instrument used to eliminate such situations is, for instance, the said asking of questions. This means the submission of an application to clarify the terms of reference resulting in the awarding entity's obligation to respond within specified deadlines. Both the questions and the answers that are published by the awarding entity create equal access to information on the part of entities applying for the contract, reducing the asymmetry between the contractors themselves and between the contractor and the awarding

\footnotetext{
${ }^{15}$ John W Pratt, Richard J. Zeckhauser, Principal and agents: The structure of business (Harvard Business School Press 1985).
} 
entity. Secondly, negative, when the awarding entity and the contractor, despite being aware of the presence of asymmetry of information do not take any steps to eliminate it. They treat the ambiguity of the message as the opportunity to maximize the utility of their own objectives. The principle of buying as cheaply as possible becomes consolidated instead of making the principle of achieving the optimum price in specific conditions of the provision of the service comes about. Therefore, they are not aiming to make use of the instruments of the law, such as competitive dialogue, the procedure of announcement and negotiation, which would enable the asymmetry of information to be reduced.

\section{Hidden Information. Hidden ACTION}

Taking into account the specificities of the public procurement system justifies drawing attention to its subjective aspect. Most of the literature on the subject focuses on "one-to-one" interactions (one principal, one agent). In practice, the "one-to-one" public procurement situation is relatively rare (e.g. in the case of natural monopolies); in the majority of cases, there are developed relationships, namely one principal, namely the awarding entity, and many potential agents, or contractors. Several contractors take part in the tendering process, trying to influence the decisions made by the awarding entity. From the point of view of the effectiveness of the public procurement system, of key importance is that the multiplicity of contractors can intensify the phenomenon of the asymmetry of information and weaken the incentives which should affect the awarding entity's decisions. This has the objective of, inter alia, countering the principle of fair competition, which is one of the fundamental rules in force in Polish public procurement law. In accordance with its wording, the awarding entity must prepare and conduct the public procurement proceedings in a manner which assures fair competition and equal treatment of contractors. Therefore, the awarding entity is responsible for compliance with this principle. The protection of competition has the objective of achieving the said optimization of the transaction between the awarding entity and the contractor, as well as the optimization of the allocation of resources, to ensure the effectiveness of the contract and the protection of the awarding entity's interests. The literature on the subject notes that the assurance of the appropriate level of competitiveness and transparency of the public procurement system leads to: (a) a reduction in the agency costs and (b) an increase in the probability of choosing the agent with the greatest potential. However, the public procurement system has a clearly focused nature; both the knowledge gathered by other academic disciplines and some of their interpretations are initially eliminated. This particularly applies to the phenomenon of ties, informal attitudes, which are out of the control of the contracting authority and which generate the effect of hidden information.

The intensity of the phenomenon of negative selection in the Polish public procurement system up to 2014 was compounded by the so-called price criteria for the selection of the proposal. The contractors offering the most competitive prices and, therefore, the contractors who are most 
inclined to bear a high risk won the tenders. Furthermore, the lowest price offered by the contractor does not mean that he is able to guarantee a high quality of fulfilment of the subject matter of the contract within the set deadline. Contractors, who were careful in their exposure to risk, namely those wishing to ensure that the task is completed within the deadline and at a satisfactory level of workmanship, offered higher prices and lost tenders. Recognizing this problem, the lawmakers strengthened the non-price criteria in the assessment of bids. When awarding a public contract, the awarding entity was required to pay more attention to the quality of the goods, services or works.

An example has been presented below of the phenomenon of hidden information and hidden action in a specific public procurement procedure. A public sector unit organized a tender for the purchase of furniture for a monumental building that it manages. Open tendering was applied five times. In each tender, in accordance with the amendment to the public procurement law, alongside the price criterion for the selection of the bid, a criterion was applied in the form of a guarantee provided by the contractor on the furniture, whereas, in the last tender, one more criterion was applied, namely the timing of the fulfilment of the contract. The course of the whole of the public procurement process is presented in the following table.

Tab. 1 Process of fulfilling the public contract

\begin{tabular}{|c|c|c|c|c|c|}
\hline \multicolumn{6}{|c|}{ OPEN TENDER NO 1} \\
\hline $\begin{array}{c}\text { Contract } \\
\text { or }\end{array}$ & Price & Guarantee & $\begin{array}{c}\text { Timing } \\
\text { of } \\
\text { completi } \\
\text { on }\end{array}$ & Evaluation criterion & $\begin{array}{l}\text { Total } \\
\text { score }\end{array}$ \\
\hline $\mathrm{T}$ & $\begin{array}{c}10018.32 \\
5\end{array}$ & $\begin{array}{c}24 \text { months } \\
(6.67)\end{array}$ & - & \multirow{2}{*}{$\begin{array}{l}\text { Price }(\mathrm{C})-90 \% \\
\text { Guarantee }(\mathrm{G})-10 \% \\
\text { Price }=(\mathrm{C} \text { lowest } / \mathrm{C} \\
\text { analysed } * 90 \\
\text { Guarantee }=(\mathrm{G} \text { analysed } \\
\text { /G longest }) * 10 \\
\text { Total } 1 . \text { points }=\mathrm{C}+\mathrm{G}\end{array}$} & 63.46 \\
\hline M & 6322.203 & $\begin{array}{l}36 \text { months } \\
\text { (10) }\end{array}$ & - & & 100.00 \\
\hline \multicolumn{6}{|c|}{ OPEN TENDER NO 2} \\
\hline $\begin{array}{c}\text { Contract } \\
\text { or }\end{array}$ & Price & Guarantee & $\begin{array}{c}\text { Timing } \\
\text { of } \\
\text { completi } \\
\text { on }\end{array}$ & Evaluation criterion & $\begin{array}{l}\text { Total } \\
\text { score }\end{array}$ \\
\hline $\mathrm{T}$ & $\begin{array}{c}24600.0 \\
0\end{array}$ & $\begin{array}{c}48 \\
\text { months } \\
(8)\end{array}$ & - & \multirow{2}{*}{ as above } & 93.50 \\
\hline $\mathrm{M}$ & $\begin{array}{c}23370.0 \\
0\end{array}$ & $\begin{array}{c}60 \\
\text { months } \\
(20)\end{array}$ & - & & 100.00 \\
\hline \multicolumn{6}{|c|}{ OPEN TENDER NO 3} \\
\hline $\begin{array}{c}\text { Contract } \\
\text { or }\end{array}$ & Price & Guarantee & $\begin{array}{c}\text { Timing } \\
\text { of }\end{array}$ & Evaluation criterion & $\begin{array}{l}\text { Total } \\
\text { score }\end{array}$ \\
\hline
\end{tabular}




\begin{tabular}{|c|c|c|c|c|c|}
\hline & & & $\begin{array}{c}\text { completi } \\
\text { on }\end{array}$ & & \\
\hline $\mathrm{T}$ & \begin{tabular}{|c|}
23141.2 \\
2
\end{tabular} & $\begin{array}{c}48 \\
\text { months } \\
(10)\end{array}$ & - & as above & 100.00 \\
\hline \multicolumn{6}{|c|}{ OPEN TENDER NO 4} \\
\hline $\begin{array}{c}\text { Contract } \\
\text { or }\end{array}$ & Price & Guarantee & $\begin{array}{c}\text { Timing } \\
\text { of } \\
\text { completi } \\
\text { on }\end{array} \mid$ & Evaluation criterion & $\begin{array}{l}\text { Total } \\
\text { score }\end{array}$ \\
\hline $\mathrm{T}$ & $\begin{array}{c}46236.6 \\
8\end{array}$ & $\begin{array}{c}24 \\
\text { months } \\
(8)\end{array}$ & - & \multirow{3}{*}{$\begin{array}{l}\text { Price }(C)-80 \% \\
\text { Guarantee }(G)-20 \% \\
\text { Price }=(C \text { lowest } / C \\
\text { analysed }) * 80 \\
\text { Guarantee }=(G \\
\text { analysed } / G \text { longest }) * \\
20 \\
\text { Total 1. points }=C+G\end{array}$} & 54.18 \\
\hline $\mathrm{M}$ & $\begin{array}{c}52484.1 \\
0\end{array}$ & $\begin{array}{c}60 \\
\text { months } \\
(20)\end{array}$ & - & & 60.68 \\
\hline $\mathrm{A}$ & $\begin{array}{c}26691.0 \\
0\end{array}$ & $\begin{array}{c}60 \\
\text { months } \\
(20)\end{array}$ & - & & 100.00 \\
\hline \multicolumn{6}{|c|}{ OPEN TENDER NO 5} \\
\hline $\begin{array}{c}\text { Contract } \\
\text { or }\end{array}$ & Price & $\begin{array}{l}\text { Guarantee } \\
\text { Weight: } \\
0-24 \\
\text { months } \\
10-25-36 \\
\text { months } \\
20-37-48 \\
\text { months }\end{array}$ & \begin{tabular}{|c|}
$\begin{array}{c}\text { Timing } \\
\text { of } \\
\text { completi } \\
\text { on }\end{array}$ \\
Weight: \\
- to \\
$16 / 12$ \\
$10-$ to \\
$j 9 / 12$ \\
$20-$ to \\
$30 / 11$
\end{tabular} & Evaluation criterion & $\begin{array}{l}\text { Total } \\
\text { score }\end{array}$ \\
\hline $\mathrm{T}$ & \begin{tabular}{|c|}
21979.4 \\
9
\end{tabular} & $\begin{array}{c}37 \\
\text { months } \\
(20)\end{array}$ & $\begin{array}{c}30 / 11 \\
(20)\end{array}$ & \multirow{3}{*}{$\begin{array}{l}\text { Price }(\mathrm{C})-60 \% \\
\text { Guarantee }(\mathrm{G})-20 \% \\
\text { Timing of completion } \\
(\mathrm{T})-20 \% \\
\text { Price }=(\mathrm{C} \text { lowest } / \mathrm{C} \\
\text { analysed }) * 60 \\
\text { Guarantee }=0 \text { or } 10 \text { or } \\
20 \\
\text { Timing of completion }= \\
0 \text { or } 10 \text { or } 20 \\
\text { Total } 1 \text {. points }=\mathrm{C}+\mathrm{G} \\
+\mathrm{T}\end{array}$} & 94.45 \\
\hline $\mathrm{M}$ & $\begin{array}{c}22841.1 \\
0\end{array}$ & $\begin{array}{c}48 \\
\text { months } \\
(20)\end{array}$ & $\begin{array}{c}30 / 11 \\
(20)\end{array}$ & & 92.40 \\
\hline $\mathrm{B}$ & $\begin{array}{c}19948.1 \\
4\end{array}$ & $\begin{array}{c}48 \\
\text { months } \\
(20)\end{array}$ & $\begin{array}{c}09 / 12 \\
(10)\end{array}$ & & 90.00 \\
\hline
\end{tabular}

Source: own study.

In spite of the mechanisms used, such as a tender deposit, the requirement for contractors to submit appropriate statements/certificates and non-price criteria for assessing bids, which should eliminate the problem of asymmetry of information, the awarding entity was unable to identify any hidden information or hidden actions of contractors. The question of 
whether the contractors had entered into any price collusion in this case has become justified. In analysing the bids that were submitted, the awarding entity was only able to notice that contractors $\mathrm{T}$ and $\mathrm{M}$ conduct the same business which is registered in two different towns in Poland. In each tender in which contractor $\mathrm{M}$ took part, it was accompanied by contractor $\mathrm{T}$. The bids were submitted separately, whereby, in every case, the bids submitted by contractor $\mathrm{M}$ were received later than contractor T's bid. Contractor T was selected as the best bidder in tender numbers 3 and 5. However, it did not sign the contract, which resulted in its forfeiture of the tender deposit. The contract was awarded to bidder $\mathrm{M}$ in tender 5 , whereas the awarding entity was forced to open another tender as a result of tender 3. Contractor $\mathrm{M}$ was selected in tender 4 , in which contractor $\mathrm{A}$ failed to provide explanations on the abnormally low prices within the prescribed period. In tenders 1 and 2, contractor T was "respectively" worse than contractor M. It seems that contractor T was a "figurehead" which agrees to lose the tender deposit, as long as $\mathrm{M}$ is chosen as the contractor in the procurement.

The simulation of the contract that was awarded in the open tender procedure justifies the assertion that, despite observing the principles of fair competition and using mechanisms to increase transparency and objectivity of the choice of a specific contractor, the awarding entity was unable to reduce the said agency costs, primarily the opportunity costs. As a result of tender 5 , the public contract is being fulfilled by contractor M, who offered the highest price. This outcome of the tender procedure was affected by contractor T's conduct, who withdrew from signing the contract, thereby forcing the awarding entity to prepare and conduct the next tender. From this point of view, the lack of verifiability, as an element of the asymmetry of information in the public procurement system is compounded by the particular situation where several potential contractors are trying to win the contract, between whom there are informal relations, which may distort the results of the tender procedure and affect the quality of performance of the contract.

\section{CONCLUSiON}

The agency theory is an attractive cognitive research tool. Only selected aspects of asymmetry of information in the public procurement system have been mentioned in this article. The acceptance of the specificities of the institutional environment, as well as the new mechanisms introduced into the public procurement system, justify the assumption that it will develop faster. The Polish Government passed an Act in 2016 adjusting the public procurement system to the requirements of the EU directives. The amendment to the Public Procurement Law that was introduced has the purpose of directly contributing to the elimination of many negative aspects of the public procurement system in Poland and, indirectly, makes it possible to eliminate the asymmetry of information between the awarding entity and the contractor. The promoters of the bill primarily indicate the decided reduction in the excessive use of price as the sole criterion for evaluating bids, as well as the solution to the problem of a lack of legal 
grounds for selecting a bid using cost accounting on the basis of the criterion of the most economically advantageous bid using life-cycle cost accounts (encompassing the costs related to acquisition, use, withdrawal from operation and the environmental cost related to the life cycle of the product, service or work). In addition, the need to apply rigid premises for applying negotiating procedures preceded by the contract notice, namely the competitive procedure with negotiations and the competitive dialogue will change to ensure the ability to select solutions that better match their expectations, which are more economic, more innovative, tailored to the needs of the awarding entity and the users of the subject matter of the contract. In the light of the proposed provisions, a very interesting field of research in this area arises from the awarding of rights to the awarding entities to audit the entities declaring that they will be benefiting from the potential of third parties in the fulfilment of the contract (the awarding entity will be able to demand of the contractor that the entity providing the potential takes part to the maximum possible extent in the fulfilment of the contract).

\section{References}

Boyne George A., 'Bureaucratic theory meets reality: public choice and service contracting in U.S. local government' (1998) 58 (6) Public Administration and Review

Brown Trevor L., Potoski Matthew, Slyke David M., 'Managing public service contracts: aligning values, institutions, and markets' (2006) 66 (3) Public Administration Review

Daly Hounaida, 'Conflicts of interest in agency theory: a theoretical overview'(2015) 15 (1) Global Journal of Human-Social Science: E Economics

Eisenhardt Kathleen M., 'Agency theory: an assessment and review' (1989) 14 (1) Academy of Management Review

Hodge Graeme A., 'Competitive tendering and contracting out: rhetoric or reality?' (1999) 22 (4) Public Productivity and Management Review

Jensen Michael C., Meckling William H., 'Theory of the firm: managerial behavior, agency cost and ownership structure' (1976) 3 (4) Journal of Financial Economics

Johnston Van R., Seidenstat Paul, 'Contracting out government services: privatization at the millennium' (2007) 30 (3) International Journal of Public Administration

Laffont Jean-Jacques, Martimort David, The theory of incentives. The Principal-Agent Model (Princeton University Press 2002)

Miroński Jacek, 'Relacja agencji w teorii przedsiębiorstwa' (2005) 164 (4) Gospodarka Narodowa

Nilakant Venkataraman, Rao Havagreeva, 'Agency theory and uncertainty in organization. An evaluation’ (1994) 15 (5) Organization Studies

Nyman Caroline, Nilsson Fredrik, Rapp Birger, 'Accountability in local government: a principal-agent perspective' (2005) 9 (2) Journal of Human Resource Costing and Accounting 
Paliński Andrzej, 'Kosztowna weryfikacja jako element relacji bankkredytobiorca' (2009) 40 (3) Bank i Kredyt.

Pratt John W., Zeckhauser Richard J., Principal and agents: The structure of business (Harvard Business School Press 1985)

Ross Stephen, 'The economic theory of agency: the principal's problem' (1973) 62 (2) American Economic Review

Schmitz Patrick W., 'On the interplay of hidden action and hidden information in simple bilateral trading problems' (2002) 1103 (2) Journal of Economic Theory

Williamson Olivier E., The economic institution of capitalism (The Free Press 1985) 